\title{
How the English Edition Happened
}

\author{
Harvey Budner
}

Tn 2010, a small group of us travelled to Ludmir (Ukrainian: Volodymyr Volynsky), a small western Ukrainian city from which my father and his family emigrated early in the nineteenth century.

Volodymyr Muzychenko, the head of the Jewish community in Ludmir and our local guide, showed us the materials for a book he was writing in Ukrainian about the history of the Jewish community in Ludmir.

I was amazed at his seriousness of purpose and dedication to the project. He had spent several years searching in Ukrainian and Russian archives. He had also collected extensive personal reminiscences and many photos from both Jews and non-Jews in the region. What was most surprising was that he is not an historian but a classical guitarist and a teacher in the local music school. The culmination of that effort is the book you now have before you.

Volodymyr knows the community exceedingly well, even though he is not a native. Although I could provide only vague descriptions of the neighborhood from family stories, he promptly took us to a house in which it is highly likely my family lived. I did know that the family occupation was barrel-making, and that production was based in their home in Ludmir. (The name "Budner" is a version of "Bodnar" which in Ukrainian means barrel-maker).

The current, Christian occupant of the home, curious as to why there were people standing in the rain looking at her house, came out to speak with us. Volodymyr identified himself and explained to her our 
interest in her home. She said the original house was at least one hundred years old with several later additions. She welcomed us in and demonstrated unusual features such as the location of former rooftop windows, consistent with venting the steam and smoke produced in barrel-making. Volodymyr identifies strongly as Jewish, but as demonstrated by this example, he has a warm and accepting attitude toward his Christian neighbors, and they toward him.

After we returned, my extended family and I helped Volodymyr publish Jewish Ludmir in the original Ukrainian. I showed it to Professor Antony Polonsky, an expert on Eastern European Jewish History at Brandeis University. He was enthusiastic about the high quality of the scholarship and the historical significance of the photos, and he felt the work clearly deserved to be translated into English. He recommended Marta D. Olynyk to translate it. Marta accepted the assignment, and she did a most thorough and careful translation. She valued the book, in part, for its description of the centuries-long and usually harmonious relationship between Jews and Christians in Ukraine (unfortunately periodically punctuated by conflict). My extended family and I supported the translation and subsequent publication of this English edition of Jewish Ludmir.

I am enormously grateful to the extensive community of family and friends, unfortunately too numerous to name, who provided invaluable assistance with this project. However, I must acknowledge those who were absolutely essential in making this project possible by providing continuing explanation, support, and encouragement. Volodymyr Muzychenko, the author, worked tirelessly on the many details of translating and publishing his book into English. Professor Antony Polonsky was my guide through a process totally unfamiliar to me. Marta D. Olynyk not only produced a superb translation of the book itself but then assisted with translating the extensive follow-up communication between the publisher and the author. Debra Young (aided by husband Arnold) made the software understandable and manageable. The staff at Academic Studies Press was immediately responsive and very cooperative in the many decisions about editing and production.

I am thrilled with the result, and I hope you find it very enlightening reading. 